University of Nebraska - Lincoln

DigitalCommons@University of Nebraska - Lincoln

\title{
A diatom record of late Holocene climate variation in the northern range of Yellowstone National Park, USA
}

\author{
Brandi B. Bracht \\ University of Nebraska-Lincoln \\ Jeffery R. Stone \\ University of Nebraska-Lincoln, jeffery.stone@indstate.edu \\ Sherilyn C. Fritz \\ University of Nebraska-Lincoln, sfritz2@unl.edu
}

Follow this and additional works at: https://digitalcommons.unl.edu/geosciencefacpub

Part of the Earth Sciences Commons

Bracht, Brandi B.; Stone, Jeffery R.; and Fritz, Sherilyn C., "A diatom record of late Holocene climate variation in the northern range of Yellowstone National Park, USA" (2007). Papers in the Earth and Atmospheric Sciences. 17.

https://digitalcommons.unl.edu/geosciencefacpub/17

This Article is brought to you for free and open access by the Earth and Atmospheric Sciences, Department of at DigitalCommons@University of Nebraska - Lincoln. It has been accepted for inclusion in Papers in the Earth and Atmospheric Sciences by an authorized administrator of DigitalCommons@University of Nebraska - Lincoln. 
Published in Quaternary International (2007); doi:10.1016/j.quaint.2007.08.043

Copyright (C) 2007 Elsevier Ltd. and the International Union for Quaternary Research (INQUA). Used by permission. http://sciencedirect.com/science/journal/10406182

Published online September 17, 2007.

\title{
A diatom record of late Holocene climate variation in the northern range of Yellowstone National Park, USA
}

\author{
Brandi B. Bracht, Jeffery R. Stone, and Sherilyn C. Fritz* \\ Department of Geosciences, University of Nebraska-Lincoln, 214 Bessey Hall, Lincoln, NE 68588-0340, USA \\ * Corresponding author-tel. 402 472-6431; fax 402 472-4917. \\ Email: B. B. Bracht bbracht@gmail.com ; J. R. Stone jstone@unlserve.unl.edu ; S. C. Fritz sfritz2@unl.edu
}

\begin{abstract}
The changes in diatom species composition in a sediment core from Crevice Lake, Yellowstone National Park, spanning the past $2550 \mathrm{yr}$, were used to reconstruct long-term limnological and ecological conditions that may be related to late Holocene climate variability. Planktic forms dominate the fossil diatom assemblages throughout this record, but changes in species dominance indicate varying nutrient levels over time, particularly phosphorus. The changes in the nutrient concentrations in the lake were probably driven by changes in temperature and wind strength that affected the duration of watercolumn mixing and thus the extent of nutrient recycling from deep waters. Prior to 2100 cal before present (BP), Stephanodiscus minutulus and Synedra tenera dominated, suggesting long cool springs with extensive regeneration of phosphorus from the hypolimnion that resulted from isothermal mixing. From 2100 to $800 \mathrm{cal}$ BP, these species were replaced by $C y$ clotella michiganiana and Cyclotella bodanica. These species are characteristic of lower nutrient concentrations and are interpreted here to reflect warm summers with long periods of thermal stratification. From 800 to 50 cal BP, S. minutulus dominated the diatom assemblage, suggesting a return to lengthy mixing during spring. The most dramatic late Holocene changes in the fossil diatom assemblages occurred during the transition from the Medieval Period to the Little Ice Age, approximately 800 cal BP.
\end{abstract}

\section{Introduction}

The Rocky Mountains are the source area for several major western rivers that provide water for cities, agriculture, and transportation systems (Downey and Dinwiddie, 1988; Changnon et al., 1991). Persistent precipitation deficits in recent years have produced severe water shortages throughout much of the region (Hidalgo, 2004). In addition, warmer winter and spring temperatures have affected the volume of mountain snow pack and the timing of seasonal snowmelt and runoff (Barnett et al., 2005; Mote et al., 2005).

Reconstruction of long-term temperature and precipitation patterns in the Rocky Mountain region using paleoclimatic archives can extend the climate record beyond the instrumental period and aid in our understanding of natural patterns of climatic variation and their environmental impacts (Cook et al., 2004). The Rocky Mountain region has a spatially variable climate, which is the product of the topographic gradi- ents and the resultant differential heating of mountain slopes, diversion or concentration of winds through mountain passes, precipitation rain shadows, amongst others. Mock (1996) suggests a complex of climatic controls that each modifies different spatial regimes within the mountainous terrain. As a result, sites that are relatively close to one another may not experience the same climate or show the same history, because each may be influenced by a synoptic climatology that is modified by the local topography (Williams et al., 1996). Tree-ring reconstructions are now available for many parts of the Rocky Mountains (e.g. Woodhouse, 2001; Cook and Krusic, 2004; Gray et al., 2004; Gray et al., 2007); however, these records can be corroborated and the history of climatic variation can be extended to longer periods of time using high-resolution analysis of lake sediments.

This study has reconstructed the climate history of the northern portion of Yellowstone National Park at approximately decadal resolution for the past $\sim 2500$ yr based on mul- 
tiple proxies from Crevice Lake, including pollen, charcoal, geochemical variables, and diatoms (Whitlock et al., 2007). Although other long paleoclimatic records have been generated from the Yellowstone region, nearly all of these are at a much coarser temporal resolution. Details are provided here on the diatom record from Crevice Lake and its environmental controls. In this particular record, the diatoms provide evidence for changes in the duration of summer stratification of the lake, which reflects the seasonal patterns in temperature and wind.

\section{Environmental setting}

Crevice Lake (lat. $45.000^{\circ} \mathrm{N}$, long. $110.578^{\circ} \mathrm{W}$, elev. $1713 \mathrm{~m}$ ) is a closed-basin deep (maximum depth $=31 \mathrm{~m}$ ) lake in Yellowstone's northern range. Vegetation in the catchment is characterized by an open forest of Pseudotsuga menziesii, Juniperus scopulorum, and Pinus flexilis, as well as steppe dominated by Artemisia tridentata and bunchgrasses. The lake's small size $(7.76 \mathrm{ha})$ and moderate depth $\left(z_{\max }=30 \mathrm{~m}\right)$ promote seasonal anoxia that results in the preservation of annually laminated sediments (varves). The lake is alkaline (total alkalinity $=240 \mathrm{mg} \mathrm{L}^{-1} \mathrm{CaCO}_{3}, \mathrm{pH}=8.0$, conductivity $=$ $620 \mu \mathrm{S}$ ) and mesotrophic ( $\mathrm{TP}=20 \mu \mathrm{g} \mathrm{L}^{-1}$; summer Secchi depth $=7.0 \mathrm{~m}$ ). The lake sits topographically above the Yellowstone River (Figure 1), and the two are separated by glacial till. The river flows north to south, several hundred meters to the west of Crevice Lake, and it is likely that the lake is hydrologically connected to the Yellowstone River. Thus, although the lake has no surface outflow, lake level is thought to be more strongly influenced by the base level of the river than by the seasonal fluctuations in effective moisture (precipitation minus evaporation, $P-E$ ).

\section{Methods}

A freeze core and a series of Austrian (piston) cores were recovered from the ice surface from $30 \mathrm{~m}$ of water depth in the Crevice Lake Basin in February 2001 (Figure 2). The cores are varved (annually laminated), and each varve consists

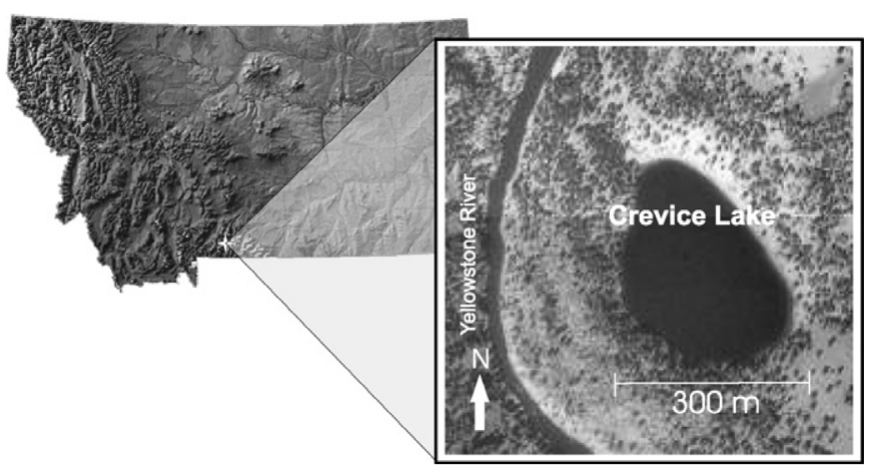

Figure 1. Shaded relief view of Montana with the star indicating the approximate location of Crevice Lake $\left(45.00^{\circ} \mathrm{N}, 110.6^{\circ} \mathrm{W}\right)$. The inset is an aerial photo showing the lake with the Yellowstone River running to the left.

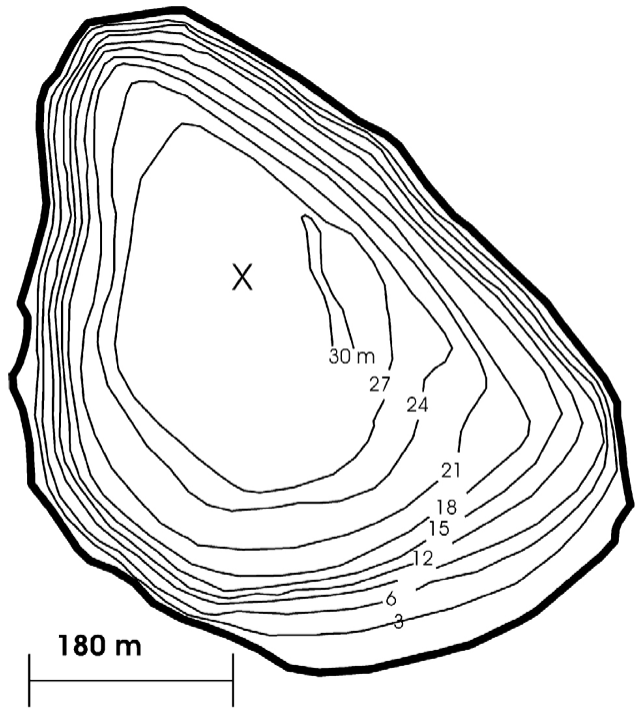

Figure 2. Bathymetric map of Crevice Lake showing the basin morphometry. The Austrian cores were taken from the deepest part of the lake basin to reduce distortion of sediments. (Figure modified from Yellowstone National Park Service bathymetric map.)

of an organic-carbonate couplet. The freeze core and the piston cores were combined into a continuous sediment sequence based on distinctive sedimentary changes present in the overlapping core sections. The core sequence was subsampled continuously along bedding planes in $2-4 \mathrm{~mm}$ intervals, and each segment was homogenized prior to subsampling for diatoms and other proxies. A chronology for the freeze and upper portions of the Austrian core sequence was established using both varve counts and ${ }^{14} \mathrm{C}$ dates from plant macrofossils. The top of the freeze core represents the year $2000 \mathrm{AD}$ or $0 \mathrm{yr}$ before present (BP). Six AMS ${ }^{14} \mathrm{C}$ dates were obtained in these core sections, and the ${ }^{14} \mathrm{C}$ ages were converted to calendar ages with Calib 5.2 (Stuiver et al., 1998) (Table 1). One of these dates was discarded, because the inverted age relative to adjoining samples indicated reworking of the material. Two varve dates plus five radiocarbon dates were fitted with a third order polynomial to create an age model (Figure 3). For the upper $2550 \mathrm{yr} \mathrm{BP}$, the average sample spacing was $7 \mathrm{yr}$.

Contiguous samples for diatom analyses were taken from the top $80.5 \mathrm{~cm}$ of the Austrian cores and the entirety of the freeze core. Samples were treated with cold hydrochloric acid and hydrogen peroxide to digest the carbonate and organic material, respectively. Rinsed samples were dried onto coverslips, and the coverslips were mounted onto slides with a permanent mounting media (Battarbee, 1986). At least 300 diatom valves were counted on each slide.

Species percent abundances were plotted against the developed chronology to determine the changes in the species abundances during the last $2550 \mathrm{yr}$. Shifts in the dominant species were used to create a zonation scheme for the diatom stratigraphy, because cluster analysis techniques did not prove useful in determining the zone boundaries. 
Table 1.

Radiocarbon ages and the calibrated age equivalents used in constructing the Crevice Lake age model

\begin{tabular}{|c|c|c|c|c|c|c|c|}
\hline Sample ID & ${ }^{14} \mathrm{C}$ lab\# & $\begin{array}{l}\text { Composite } \\
\text { depth }(\mathrm{cm})\end{array}$ & Material & $\begin{array}{l}{ }^{14} \mathrm{C} \text { age } \\
(\text { yr BP) }\end{array}$ & $\begin{array}{l}\text { Age error } \\
\text { (yr) }\end{array}$ & $\begin{array}{l}\text { Calibrated range } 2 \\
\text { sigma (cal BP) }\end{array}$ & $\begin{array}{l}\text { Midpoint } \\
\text { (cal BP) }\end{array}$ \\
\hline CV-25 & WW-4618 & 20.45 & Needle & 210 & 55 & 59-320 & 190 \\
\hline CV-108/109 & WW-4619 & 49.45 & Needle & 1010 & 55 & 791-1010 & 900 \\
\hline CV-184 & WW-4626 & 75.85 & Needle & 1920 & 120 & $1562-2149$ & 1855 \\
\hline$C V-213^{a}$ & WW-4620 & 83.85 & Bark & 2390 & 45 & 2337-2519 & 2428 \\
\hline CV-272 & WW-4621 & 104.15 & Needle & 2500 & 80 & $2362-2742$ & 2552 \\
\hline
\end{tabular}

Samples for radiocarbon dating were prepared in the USGS ${ }^{14} \mathrm{C}$ laboratory in Reston, VA, and analyzed at the Lawrence Livermore National Laboratory (CAMS).

${ }^{\text {a }}$ Not used in the construction of the age-depth model.

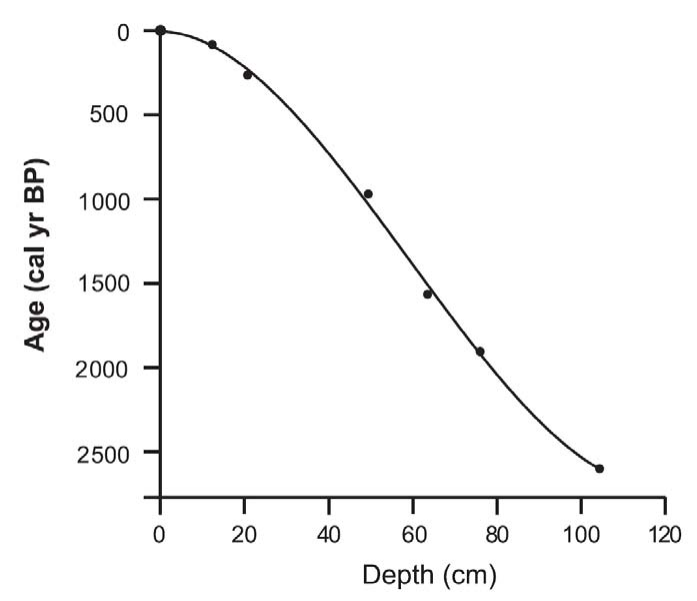

Figure 3. Age-depth relationship for Crevice Lake (see text for details).

\section{Results}

The sampled portions of the core consisted of dark to light brown laminated gyttja with intermittent nodules. Few distinct color changes were noticeable along the sequence. The laminations are extremely fine couplets, averaging less than $0.3 \mathrm{~mm}$ in thickness, and are likely varves, based on a comparison of counts of couplets and the calibrated ${ }^{14} \mathrm{C}$ ages. The ${ }^{14} \mathrm{C}$ ages are used in combination with the varves, because the thinness limits confidence in identifying all the varves.

A zonation scheme for the diatom stratigraphy was constructed based on the changes in the abundance patterns of the four dominant species, Stephanodiscus minutulus, Cyclotella bodanica, Cyclotella michiganiana, and Synedra tenera (Figure 4). The determination of the sub-zones within zone 2 was based upon whether or not $C$. michiganiana consistently reached 20\% abundance. The divisions within zone 3 were based on the rapid alterations in dominance between $S$. minutulus and C. bodanica.

Zone 1 (2550-2100 cal BP) (Figure 4) is characterized by S. minutulus and S. tenera. Zone $2(2100-800 \mathrm{cal} \mathrm{BP})$ con- sists of seven sub-zones. Sub-zone 2A is dominated by C. bodanica, with occurrences of $C$. michiganiana that rarely exceed 20\% (2100-1550 cal BP). Benthic diatoms are abundant during this zone. Sub-zone 2B (1550-1390 cal BP) is characterized by higher abundances of $C$. michiganiana (40-75\%), although $C$. bodanica remains prominent during this period. During the deposition of sub-zone 2C (1390-1300 cal BP), C. bodanica returns to dominance (80-90\%) with a sudden decrease in C. michiganiana (5\%). The abrupt dominance (40$60 \%)$ of C. michiganiana characterizes sub-zone 2D (13001290 cal BP). The absence of C. michiganiana and the dominance of $C$. bodanica (79-90\%) distinguish sub-zone 2E (1290-1050 cal BP). After this period, C. michiganiana again exhibits spikey dominance (1050-920 cal BP), which defines sub-zone 2F. The last sub-zone, 2G (920-800 cal BP), is defined by the dominance of $C$. bodanica and almost complete disappearance of $C$. michiganiana.

Zone 3 has three major sub-zones. During the first subzone, 3A (800-245 cal BP), S. minutulus dominates, but $C$. bodanica is still prominent. In sub-zone 3B (245-150 cal BP), S. minutulus drops sharply in abundance, while $C$. bodanica dominates. In the most recent sub-zone, 3C (150-0 cal BP), both $C$. bodanica and $S$. minutulus are the most common taxa, but shifts in abundance occur very rapidly throughout this period. Fragilaria capucina is also prominent during this interval, but this species never dominates the assemblage.

\section{Discussion}

\subsection{Diatom paleoecology}

The dominant feature of the Crevice Lake diatom record is the alternation in dominance between $S$. minutulus and $C$. bodanica. Modern ecological data from surface-sample calibrations consistently show that $S$. minutulus is characteristic of higher phosphorus conditions than $C$. bodanica. For example, in eastern Canada the phosphorus optimum for C. bodanica is $10.0 \mu \mathrm{g} \mathrm{L}^{-1}$, while $S$. minutulus has an optimum of $13.9 \mu \mathrm{g} \mathrm{L}^{-1}$ (Reavie et al., 1995). In the Yellowstone region, phosphorus is abundant in the andesitic soils that are characteristic of the northern range (Theriot et al., 1997). However, the inter-annual variations in phosphorus supply to planktic 


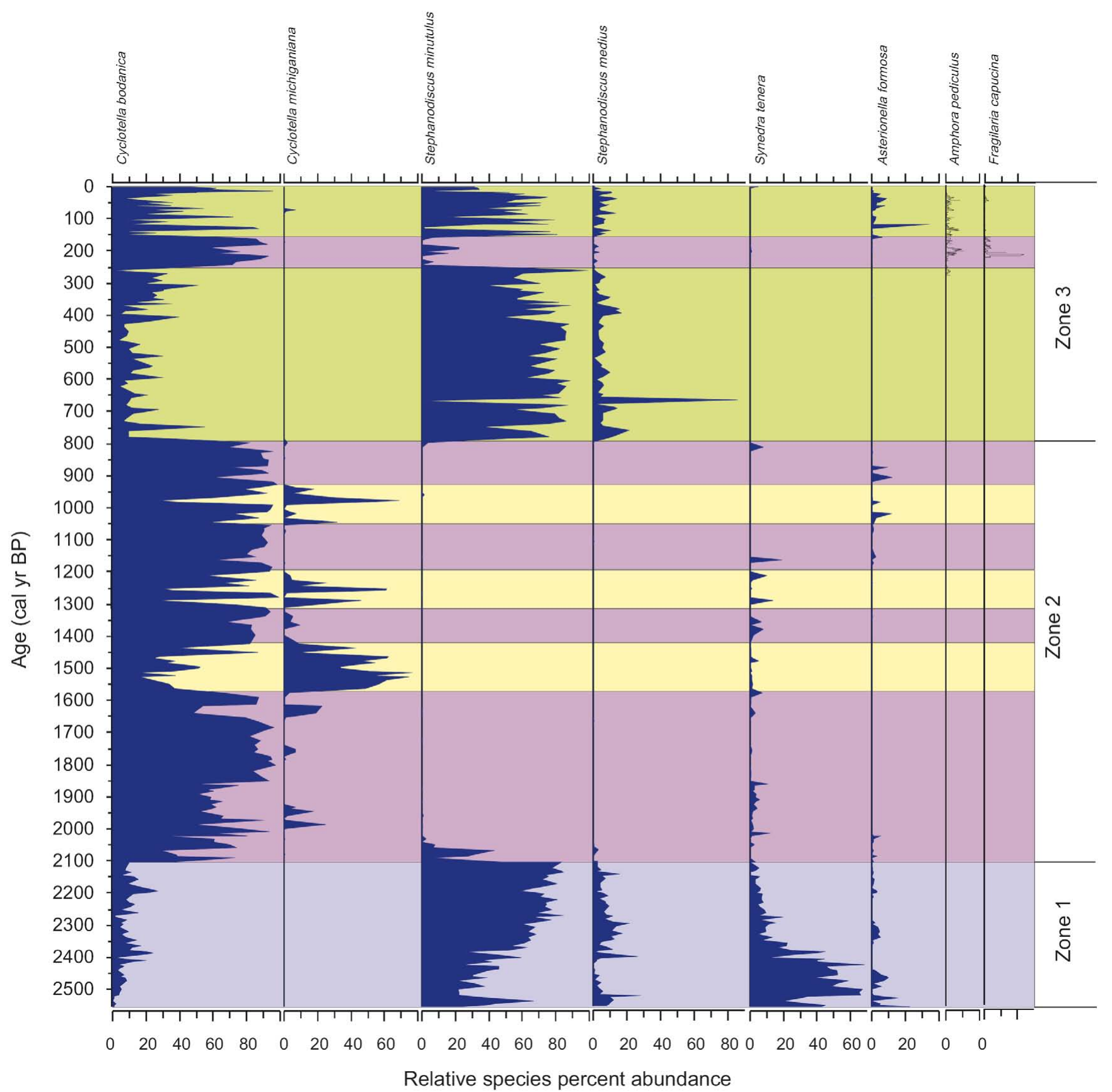

Figure 4. Zonation scheme for approximately the past 2550 yr. Species relative percent abundance are plotted against time (cal BP). The white (blue) designates when Stephanodiscus minutulus dominates, but Synedra tenera is abundant (zone 1). The dominance of C. bodanica is the medium gray (purple) (zone 2, subzones 2A, 2C, 2E, and 2G; zone 3, sub-zone 3B). The lightest gray (green) shade denotes the dominance of S. minutulus (zone 3, sub-zones 3A and 3C). C. michiganiana occurrences of greater than $20 \%$ are the darkest gray (yellow) (zone 2, sub-zones 2B, 2D, and 2F).

diatoms in Crevice Lake are most likely related to changes in water-column mixing and internal regeneration of phosphorus, rather than supply from the lake catchment (Theriot et al., 1997; Interlandi et al., 1999). During mixing, phosphorus is regenerated from the hypolimnion, which creates conditions favorable for species that can utilize the nutrient quickly or that require high phosphorus concentrations to flourish, such as $S$. minutulus or $S$. medius. Once mixing has ended, and stratification occurs, the lower phosphorus concentrations in the epilimnion favor $C$. bodanica.

Based on this model, the prominent fluctuations in the dominance between $C$. bodanica and $S$. minutulus likely reflect changes in lake water chemistry that are associated with the duration of isothermal mixing in spring relative to periods of thermal stratification in summer. C. bodanica blooms when phosphorus is in low supply, nitrogen is relatively 
abundant, and overall phytoplankton biomass is low (Interlandi et al., 1999). In the Yellowstone region lakes, it is most common in the summer months during times of water-column stratification. It often forms a layer of cells near the thermocline, where nitrogen is higher in concentration than in the rest of the water column. S. minutulus populations are characteristic of low N:P and Si:P ratios, and this species blooms, in Yellowstone lakes, in early spring during times of isothermal mixing (Kilham et al., 1996; Interlandi et al., 1999). Because $S$. minutulus and $C$. bodanica bloom during two different times of the year, spring and summer, the two species are never in direct competition for nutrients. Nonetheless, large S. minutulus blooms during spring mixing may remove sufficient phosphorus and other micronutrients from the water column. Nutrient availability is then reduced for subsequent algal species, such as $C$. bodanica, which prevents them from blooming in the summer months. Conversely, if spring mixing is incomplete or truncated, S. minutulus may remove less phosphorus from the system, allowing larger populations of species that bloom later in the summer. In northern Minnesota, a similar combination of water-chemistry and stratification conditions was observed in association with these taxa. Using data from seasonal traps in Elk Lake, MN, Bradbury (1988) found that S. minutulus bloomed during the spring mixing season and declined rapidly during the onset of summer stratification, while this stratification was required for the dominance of $C$. bodanica.

The correspondence of $S$. minutulus and $C$. bodanica with nutrient variability that is strongly associated with seasonal differences in the length of the period of isothermal mixing relative to the period of stratification suggests that their abundance is linked to climatic drivers that control the lake thermal structure (Bradbury, 1988). Various factors, such as thin ice cover, early cool windy springs, and delayed summer warming, contribute to protracted periods of deep water circulation (Bradbury, 1988). Under these conditions, species assemblages with high nutrient requirements, such as S. minutulus, should dominate longer into the summer months (Kilham et al., 1996).

Shifts in some of the sub-dominant species, such as Asterionella formsosa and $S$. tenera, are also likely related to changes in the lake thermal structure. Both the species are extremely efficient under low-phosphorus conditions and, in the Yellowstone region lakes, increase in relative abundance after S. minutulus blooms (Interlandi et al., 1999) but prior to the onset of stratification. Thus, these species may be indicative of years of particularly long periods of isothermal mixing.

Little is known about the specific nutrient requirements of C. michiganiana or Cyclotella ocellata relative to C. bodanica, although overall these Cyclotella species also are characteristic of lower phosphorus concentrations than Stephanodiscus spp. We speculate that these taxa bloom under conditions of more protracted summer stratification (with $C$. ocellata blooming under the most $\mathrm{N}$-limiting conditions) than C. bodanica.
The dominant influence of thermal stratification on the diatom assemblages in the Crevice Lake record is corroborated by the stratigraphy of other proxies analyzed from the same sequence (Whitlock et al., 2007). For example, redox-sensitive elements, such as sulfur, show patterns of change similar to those observed in the diatom record. Thus, the duration of summer stratification affects the oxygen concentrations at the sediment water interface and the solubility and the phase of redox-sensitive elements. In contrast, the pollen and the charcoal reconstructions show little direct relationship to the higher frequency changes in the diatom record, suggesting that variation in vegetation and fire are not likely drivers of changes in the limnological environment.

Amphora pediculus, which is epiphytic, is the most common benthic species in the upper Crevice Lake sediments. Increases in its abundance probably reflect increased macrophyte growth, possibly associated with years of high light penetration because of the reduced phytoplankton biomass. Overall benthic species are rare in the Crevice Lake stratigraphic record, likely because of the high productivity of planktic diatoms, which reduced the proportion of benthic diatoms in the sediments. In addition, most of the lake is moderately deep, even the shelf area at the southwest margin of the lake (Figure 2).

\subsection{Implications for paleoclimate history}

The dominance of $S$. minutulus in sub-zones 3A (800$245 \mathrm{cal} \mathrm{BP}$ ) and 3C (150-0 cal BP) in the upper portion of the core, as well as in zone 1 (2550-2100 cal BP) suggests periods of extended water-column mixing produced by long, cool, windy springs. Sub-zone 3B (245-150 cal BP) has lower proportions of $S$. minutulus, than the intervals immediately before or after, which suggests that the spring season was milder and/or shorter such that the onset of stratification was earlier in the year.

The absence of $S$. minutulus and $S$. medius from the diatom record between 2100 and $800 \mathrm{cal} \mathrm{BP}$ suggests that the spring mixing season was short during this time, probably because of warmer spring and summer temperatures that produced extended summer stratification. This inference is corroborated by an increase in pyrite and other redox-sensitive elements at the same time (Whitlock et al., 2007). Fluctuations in dominance between C. michiganiana and C. bodanica in this zone are thought to reflect changes in the nutrient concentrations and the length of the stratified period, but the exact interactions between these two species are not known.

Benthic diatoms, which grow in shallow water, persist at low levels between 2550 and $800 \mathrm{cal} \mathrm{BP}$, with highest abundance at $1900 \mathrm{cal}$ BP. Because of Crevice Lake's morphometry, an increase in benthic diatom abundance does not necessarily imply that lake levels decreased (Stone and Fritz, 2004). The lake has a broad shelf, but it is moderately deep (Figure 2). Moreover, lake-level changes are likely most strongly influenced by groundwater interactions with the nearby Yellow- 
stone River; porous glacial till separates the lake basin from the river, and this connection would act as a buffer against the drastic water level changes caused by drought (Almendinger, 1990). Given these constraints, the increased abundance of benthic diatoms probably reflects times when high water clarity maximized benthic diatom growth. In this case, the coincidence of increased benthic diatom abundance with times of prolonged summer stratification likely reflects high water clarity. This is consistent with the low summer nutrient concentrations in the epilimnion, as suggested by the dominance of Cyclotella species (see above), and with limnological studies of modern Yellowstone lakes that show high Secchi depth during times of summer stratification (Interlandi et al., 1999).

\subsection{Comparison to regional records}

Several reconstructions of late Holocene climatic conditions are available for the Yellowstone region. Mammalian fossil records show some similarity in trends to the patterns evident in the Crevice Lake diatom record, particularly a more mesic faunal assemblage between 700 and $100 \mathrm{cal} \mathrm{BP}$ than during the previous times (Hadley, 1996). The onset of this major change roughly corresponds to the warmer springs inferred in the Crevice record prior to $800 \mathrm{cal} \mathrm{BP}$. Fire-frequency records are influenced by and respond to climatic drivers similar to those that affect lake stratification patterns, and these records are often sampled at similar scales. Meyer et al. (1992) suggest that fire frequency was influenced by drier summers during the time spans $2800-1650$ and $1000-750 \mathrm{cal} \mathrm{BP,} \mathrm{with}$ the maximum number of fires during the Medieval Climatic Anomaly (1000-800 cal yr BP). Other regional fire records, based on the analysis of lake cores, show broad-scale similarities, in that they show evidence for cooling during the Little Ice Age interval and warming during the Medieval Climatic Anomaly (Pierce et al., 2004).

Several paleoclimatic records within Montana show largescale changes with the same timing as those in the diatom record from Crevice Lake. Tree-ring reconstructions from northern Yellowstone National Park show major droughts in the 13th century, as well as in the mid-18th through mid-19th centuries (Gray et al., 2007), which roughly correspond to changes within the Crevice Lake diatom record. This suggests that the climate changes at these times may have affected both temperature seasonality and precipitation. The diatom record from Foy Lake, in northwestern Montana, shows little similarity to the Crevice Lake record, because it records primarily changes in $P-E$ (Stevens et al., 2006; Stone and Fritz, 2006). In contrast, major shifts in the vegetation and fire history of Foy Lake (Power et al., 2006), which are interpreted to reflect temperature changes during the spring and summer growing season, occur at 2125 and $750 \mathrm{yr} \mathrm{BP}$, similar in timing to the major shifts in the Crevice Lake diatom record. The higher frequency shifts within the Crevice Lake diatom record, however, are not evident in the Foy Lake pollen record, probably because of its coarser resolution.
Dendrochronology from tree kill dates suggests that glacial advances occurred at 850-650, 754-625, 300-275, and 175-150 cal BP (adjusted from AD dates) in the southern Canadian Rockies (Luckman, 2000). The major shift in diatom species abundance indicative of cooler springs occurs in the 850-650 cal BP interval, but this is the only consistent period of positive correlation between the two data sets. The intervals 300-275 and 175-150 cal BP correspond to spikes in C. bodanica, but several other increases of similar magnitude occur that do not correspond to glacial advance. Therefore, a consistent correlation does not exist between these two records. The sites used for the dendrochronological study are between $50^{\circ} \mathrm{N}$ and $54^{\circ} \mathrm{N}$, while Crevice Lake is at $45^{\circ} \mathrm{N}$, and thus the differences in the reconstructed climatic histories may result from differences in the relative synoptic climatology. Additionally, the two records are not necessarily recording the same type of climate signal. Glacial advances imply cooler summer temperatures, which may or may not be well connected with the spring conditions that influence lake stratification. Overall, however, the glacial advances and cooling inferred from the Crevice Lake diatom record occurred during the Little Ice Age interval, which persisted from approximately 800-150 cal BP (Luckman, 2000). Subsequently, glaciers retreated toward their present-day positions.

The climate shift that affected the Yellowstone region at roughly $800 \mathrm{cal}$ BP is evident in many parts of western and central North America (Woodhouse and Overpeck, 1998; Laird et al., 2003; Goble et al., 2004; Booth et al., 2006), which suggests that changes in Pacific and/or Atlantic sea-surface temperatures altered the atmospheric circulation patterns across North America. In addition, there is more limited evidence for a major climatic shift at roughly 2100 cal BP (Laird et al., 1996; Anderson et al., 2005; Denniston et al., 2007; Miao et al., 2007), which also may reflect a large-scale change in the continental circulation.

\section{Acknowledgments}

Field and coring assistance was provided by the YNP Fire Cache staff, K. Pierce, C. Whitlock, J. Rosenbaum, W. Dean, L. Stevens, M. Power, L. Doner, J. Honke, and G. Skip. Varve counts were completed by L. Stevens, and core chronology was developed by L. Stevens and J. Rosenbaum. Funding and logistical support for the project was provided by Yellowstone National Park, the US Geological Survey, and the Canon Foundation. Karlyn Westover helped with data analysis and ideas that greatly improved this paper.

\section{References}

Almendinger, 1990 - J. Almendinger, Groundwater control of closedbasin lake levels under steady-state conditions, Journal of Hydrology 112 (1990), pp. 293-318. 
Anderson, 2005 - L. Anderson, M. Abbott, B. Finney and S. Burns, Regional atmospheric circulation change in the North Pacific during the Holocene inferred from lacustrine carbonate oxygen isotopes, Yukon territory, Canada, Quaternary Research 64 (2005), pp. 21-35.

Barnett et AL., 2005 — T. Barnett, J. Adam and D. Lettenmaier, Potential impacts of a warming climate on water availability in snow-dominated regions, Nature 438 (2005), pp. 303-309.

BatTARBEe, 1986 — R. Battarbee, Diatom analysis. In: B. Berglund, Editor, Handbook of Holocene Palaeoecology and Palaeohydrology, Wiley, New York (1986), pp. 527-570.

Bоотн ET AL., 2006 - - R. Booth, N. Notaro, S. Jackson and J. Kutzbach, Widespread drought episodes in the western Great Lakes region during the past 2000 years: geographic extent and potential mechanisms, Earth and Planetary Science Letters 242 (2006), pp. 415-427.

BradBury, 1988 J. Bradbury, A climatic-limnologic model of diatom succession for paleolimnological interpretation of varved sediments in Elk Lake, Minnesota, Journal of Paleolimnology 1 (1988), pp. 115-131.

Changnon et AL., 1991 — D. Changnon, T. McKee and N. Doesken, Hydroclimate variability in the Rocky Mountains, Water Resources Bulletin 27 (1991), pp. 733-743.

Cook And Krusic, 2004 - Cook, E., Krusic, P., 2004. The North American Drought Atlas. Lamont-Doherty Earth Observatory and the National Science Foundation. http://iridl.ldeo.columbia.edu/SOURCES/. LDEO/.TRL/.NADA2004/.pdsi-atlas.html

CooK ET AL., 2004 - E. Cook, C. Woodhouse, C. Eakin, D. Meko and D. Stahle, Long-term aridity changes in the western United States, Science 306 (2004), pp. 1,015-1,018.

Denniston ET AL., 2007 — R. Denniston, M. DuPree, J. Dorale, Y. Asmerom, V. Polyak and S. Carpenter, Episodes of late Holocene aridity recorded by stalagmites from Devil's Icebox Cave, central Missouri, USA, Quaternary Research 68 (2007), pp. 45-52.

Downey and Dinwiddie, 1988 — Downey, J., Dinwiddie, G., 1988. The regional aquifer system underlying the northern Great Plains in parts of Montana, North Dakota, South Dakota, and Wyoming — summary: U.S. Geological Survey Professional Paper 1402-A, pp. A1-A64.

Goble et AL., 2004 - R. Goble, J. Swinehart, J. Mason and D. Loope, Optical and radiocarbon ages of stacked paleosols and dune sands in the Nebraska Sand Hills, USA, Quaternary Science Reviews 23 (2004), pp. 1173-1182.

Gray ET AL., 2007 - S. Gray, L. Graumlich and J. Betancourt, Annual precipitation in the Yellowstone National Park region since AD 1173, Quaternary Research 68 (2007), pp. 18-27.

Gray ET AL., 2004 — S.T. Gray, L.J. Graumlich, J.L. Betancourt and G.D. Pederson, A tree-ring based reconstruction of the Atlantic Multidecadal Oscillation since 1567 AD, Geophysical Research Letters 31 (2004), p. L12205.

HadLey, 1996 - E. Hadley, Influence of late-Holocene climate on northern Rocky Mountain mammals, Quaternary Research 46 (1996), pp. 298-310.

HidALGo, $2004-\mathrm{H}$. Hidalgo, Climate precursors of multidecadal drought variability in the western United States, Water Resources Research 40 (2004), p. W12504.

InTERLANDI, 1999 - S.J. Interlandi, S.S. Kilham and E.C. Theriot, Responses of phytoplankton to varied resource availability in large lakes of the Greater Yellowstone Ecosystem, Limnology and Oceanography 44 (1999), pp. 668-682.

KiLham ET AL., 1996 - S. Kilham, E. Theriot and S. Fritz, Linking planktonic diatoms and climate change in the large lakes of the Yellowstone ecosystem using resource theory, Limnology and Oceanography 41 (1996), pp. 1052-1062.

LAIRD ET AL., 1996 — K. Laird, S. Fritz, E. Grimm and P. Mueller, Century-scale paleoclimatic reconstruction from Moon Lake, a closedbasin lake in the northern Great Plains, Limnology and Oceanography 41 (1996), pp. 890-902.
LAird ET AL., 2003 - K. Laird, F. Cumming, S. Wunsam, A. Rusak, R. Oglesby, S. Fritz and P. Leavitt, Lake sediments record large-scale shifts in moisture regimes across the northern prairies of North America during the past two millennia, Proceedings of the National Academy of Sciences 100 (2003), pp. 2483-2488.

LucKman, 2000 - B. Luckman, The Little Ice Age in the Canadian Rockies, Geomorphology 32 (2000), pp. 357-384.

Meyer et AL., 1992 - G. Meyer, S. Wells, R. Balling and A. Jull, Response of alluvial systems to fire and climate change in Yellowstone National Park, Nature 357 (1992), pp. 147-150.

Miao et AL., 2007 - X. Miao, J. Mason, J. Swinehart, D. Loope, P. Hanson, R. Goble and X. Liu, A 10,000 year record of dune activity, dust storms, and severe drought in the central Great Plains, Geology 35 (2007), pp. 119-122.

Mock, 1996 - C. Mock, Climatic controls and spatial variations of precipitation in the western United States, Journal of Climate 5 (1996), pp. 1111-1125.

Mote ET AL., 2005 - P.W. Mote, A.F. Hamlet, M.P. Clark and D.P. Lettenmaier, Declining mountain snowpack in western North America, Bulletin of the American Meteorological Society 86 (2005), pp. 39-49.

National Park Service, N.D. - National Park Service, n.d. Crevice Lake Bathymetric Map. National Park Service, Yellowstone National Park, unpublished.

Pierce et AL., 2004 - J. Pierce, G. Meyer and J. Timothy, Fire-induced erosion and millennial-scale climate change in northern ponderosa pine forests, Nature 432 (2004), pp. 87-90.

Power ET AL., 2006 - M. Power, L. Stevens, C. Whitlock and P. Bartlein, Fire and vegetation history during the last 3800 years in northwestern Montana, Geomorphology 75 (2006), pp. 420-436.

Reavie et AL., 1995 - E. Reavie, R. Hall and J. Smol, An expanded weighted-averaging model for inferring past total phosphorus concentrations from diatom assemblages in eutrophic British Columbia (Canada) lakes, Journal of Paleolimnology 14 (1995), pp. 49-67.

Stevens et AL., 2006 - L. Stevens, J. Stone, J. Campbell and S. Fritz, A 2200-yr record of hydraulic variability from Foy Lake, Montana, USA, inferred from diatom and geochemical data, Quaternary Research 65 (2006), pp. 264-274.

Stone and Fritz, 2004 - J. Stone and S. Fritz, Three-dimensional modeling of lacustrine diatom habitat areas: improving paleolimnological interpretation of planktic:benthic ratios, Limnology and Oceanography 49 (2004), pp. 1540-1548.

Stone and Fritz, 2006 - J. Stone and S. Fritz, Multi-decadal drought and Holocene climate instability in the Rocky Mountains, Geology 34 (2006), pp. 409-412.

Stuiver ET AL., 1998 - M. Stuiver, P. Reimer and E. Bard, INTCAL98 radiocarbon age calibration 24,000-0 cal BP, Radiocarbon 40 (1998), pp. 1041-1083.

Theriot ET AL., 1997 — E. Theriot, S. Fritz and R. Gresswell, Long-term limnological data from the larger lakes of Yellowstone National Park, Wyoming, USA, Arctic and Alpine Research 29 (1997), pp. 304-314.

Whitlock et AL., 2007 — Whitlock, C., Dean, W., Rosenbaum, J., Stevens, L., Fritz, S., Bracht, B., Power, M., 2007. A 2650-year-long record of environmental change from Northern Yellowstone National Park based on a comparison of multiple proxy data. Quaternary International, this issue, doi:10.1016/j.quaint.2007.06.005.

Williams ET AL., 1996 - M. Williams, M. Losleben and N. Caine, Changes in climate and hydrological responses in a high-elevation catchment in the Rocky Mountains, USA, Limnology and Oceanography 41 (1996), pp. 939-946.

Woodhouse, 2001 - C. Woodhouse, A tree-ring reconstruction of streamflow for the Colorado Front Range, Journal of the American Water Resources Association 37 (2001), pp. 561-570.

WoOdHOUSE AND OverPeCK, 1998 - C. Woodhouse and J. Overpeck, 2000 years of drought variability in the central United States, Bulletin of the American Meteorological Society 79 (1998), pp. 2693-2714. 